\title{
Javaslat az idôrétegtani (kronosztratigráfiai) egységek magyar elnevezésére és írásmódjára
}

\author{
PÁlfy József ${ }^{1,2}$, GERCSÁK Gábor ${ }^{3}$, HeGYesi Eszter ${ }^{4}$ \\ ${ }^{1}$ Eötvös Loránd Tudományegyetem, Általános és Alkalmazott Földtani Tanszék, 1117 Budapest, Pázmány Péter sétány 1/C, e-mail: palfy@elte.hu \\ ${ }^{2}$ MTA-MTM-ELTE Paleontológiai Kutatócsoport, 1117 Budapest, Pázmány Péter sétány 1/C \\ ${ }^{3}$ Eötvös Loránd Tudományegyetem, Térképtudományi és Geoinformatikai Tanszék, 1117 Budapest, Pázmány Péter sétány 1/A, \\ e-mail: gercsak@map.elte.hu \\ ${ }^{4}$ Eötvös Loránd Tudományegyetem, Földtudományi Központ, 1117 Budapest, Pázmány Péter sétány 1/C, e-mail: eszterbernadett@ gmail.com
}

\begin{abstract}
Recommended Hungarian names and orthography of chronostratigraphic units
Abstract

The geological time scale, officially compiled and maintained by the International Commission on Stratigraphy and published as the International Chronostratigraphic Chart, constitutes a fundamental standard used in the geological sciences, especially in stratigraphy. Here a translated Hungarian version of the chart is presented and a unified usage and orthography of stratigraphic names is proposed. The given Hungarian terms are primarily derived from their English equivalents, following a loosely defined principle of "consistent inconsistency with exceptions". This practice acknowledges that in the 21st century the dominant language of scientific literature is English and thus terminology in other languages is also heavily influenced by prevailing English usage. Minor changes are recommended with respect to names previously in use in the Hungarian stratigraphic vocabulary. During the nearly 20 years since the publication of the last similar Hungarian guide, several new names have been introduced to the time-scale for stratigraphic units which previously were without a widely-used Hungarian name. Adherence to the recommendations made here would promote unified and proper use of stratigraphic terms in the Hungarian geological literature.
\end{abstract}

Keywords: International Commission on Stratigraphy, stratigraphic chart, geological time scale, terminology

Összefoglalás

A földtan, azon belül különösen a rétegtan alapvető nemzetközi standardja a földtörténeti időskála, hivatalosan a Nemzetközi Rétegtani Bizottság által közreadott időrétegtani (más néven kronosztratigráfiai) táblázat. Ennek magyar fordításával a táblázatban szereplő egységek magyar elnevezésére és írásmódjára teszünk javaslatot. Mivel a 21. századi tudomány nemzetközi szakirodalma túlnyomóan angol nyelvú, a magyar névhasználatot is az angol nevekből vezetjük le a „következetes következetlenség kivételekkel” elve alapján. A hazai szakirodalomban gyakori használatban lévő nevek némelyikénél kisebb változtatás indokolt. A korábbi hasonló útmutató kiadása óta eltelt közel két évtizedben számos új egységet is bevezettek az időskálába, melyeknek korábban nem volt elterjedten használt magyar neve. Javaslataink követése elősegítheti a szaknyelvi nyelvhasználat helyességét és egységességét.

Kulcsszavak: Nemzetközi Rétegtani Bizottság, rétegtani táblázat, földtörténeti idôskála, szaknyelvi nevezéktan

\section{Bevezetés}

A földkéreg képződményeinek rétegtani tagolása és a földtörténeti idő szakaszolása a földtudományok múvelésében kiemelkedő jelentôségú. A globális tudomány számára ezért nélkülözhetetlen standardot jelent az International Chronostratigraphic Chart (CoHEN et al. 2013), azaz a nemzetközi időrétegtani (kronosztratigráfiai) táblázat, melyet szokás földtörténeti időskálának is nevezni. A kétféle név oka az a kettősség, hogy a skála egységei egyazon néven, egyszerre jelentik a földtörténeti idő egy szeletét (azaz geo- kronológiai egységeket) és az ez idő alatt képződött kőzetek összességét (kronosztratigráfiai egységeket). Ez a gyakorlat az egységesítő törekvések (ZALASIEWICZ et al. 2004) ellenére mindmáig elfogadott. Az egységek alsó határát a modern kronosztratigráfiai gyakorlat GSSP-k, globális standard sztratotípusszelvények és pontok kijelölése alapján rögzíti (CowIE et al. 1986, RemANE et al. 1996, SMITH et al. 2014). Ezek kijelölése az IUGS (International Union of Geological Sciences, Geológiai Tudományok Nemzetközi Uniója) alá tartozó ICS (International Commission on Stratigraphy, Nemzetközi Rétegtani Bizottság) feladata, amelyet annak 
albizottságaiban és azok munkacsoportjaiban folyó, tudományos konszenzusra törekvő munka és szabályozott módon történő szavazások útján valósít meg. Ehhez a nemzetközi standardhoz a magyar szakmai közösségnek is kötelező igazodnia, és ezt segítendő készült el a „Nemzetközi időrétegtani táblázat” az ICS „International Chronostratigraphic Chart" magyar fordításaként.

A táblázat magyar változata (1. ábra) az ICS honlapján (www.stratigraphy.org) érhetô majd el az eddig megjelent 18 különböző nyelvú fordításhoz hasonlóan, és reményeink szerint hasznosan fogja szolgálni a földtudománnyal foglalkozó hazai kutatói, oktatói, hallgatói szakmai közösséget és a tudományra nyitott nagyközönséget egyaránt. Mivel a rétegtani egységek nevei a magyar földtudományi szaknyelv kritikusan fontos elemei, ebben a rövid tanulmányban öszszefoglaljuk azokat az elveket és megfontolásokat, amelyek alapján összeállítottuk a táblázat fordításakor használt névkészletet. Korábban hasonló céllal készült CsÁszÁR (2002) munkája, azonban részben a nemzetközi táblázatba azóta bevezetett nevek megjelenése, részben a magyar névhasználat pontosításának és következetesebbé tételének igénye szükségessé tette annak frissítését. Az itt alkalmazott szaknyelvi helyesírási megközelítésünk alapját egyfelől a mindennapi rétegtani kutatói, oktatói, szerzői és szerkesztői gyakorlat szempontjai, másfelől a Magyar Tudományos Akadémia Magyar Nyelvi Osztályközi Állandó Bizottságában, illetve a Földrajzinév-bizottságban szerzett tapasztalat adja. Javaslatainkat a Magyar Tudományos Akadémia Földtudományok Osztálya szervezetébe tartozó Rétegtani Albizottság véleményezte és támogatja.

\section{Alapelvek és megfontolások}

Számos kérdést vetett fel a táblázatban használt magyar rétegtani nevek alakja és írásmódja, mert azok nem minden esetben vezethetôk le egyértelmúen a magyar helyesírás szabályaiból (MAGYAR TUdOMÁNYOS AKADÉMIA 2015). Ezért a szaknyelvi nyelvhasználat és helyesírás körébe tartoznak. Fontosnak tartjuk, hogy a helyes magyar nevek használata közösségi elfogadáson alapuljon. Ennek érdekében az alábbiakban pontokba szedve foglaljuk össze a névhasználati javaslataink elvi és gyakorlati alapjait. Több esetben érvelünk úgy, hogy nincs jelenleg egyedüli helyes megoldás, ezért a javasolt magyar név mellett elfogadhatónak tartunk más írásmódú változatot is. Alternatívák esetén a hagyományokkal rendelkező írásmód azonnali megszűnését nem tartjuk sem elvárhatónak, sem erôltethetônek. Sokkal inkább véljük azt, hogy a javasolt és előnyben részesített névváltozat elterjedése az alábbi érvrendszer szerint követi a szaknyelv természetes evolúcióját.

A nevek eredetének forrását elsődlegesen a Geologic Time Scale 2004 (GradsteIN et al. 2004), ill. a Geologic Time Scale 2012 (GRADSTEIN et al. 2012) referenciamunkák közlik. A 2012 után bevezetett egységek neveinek forrását az Episodesban vagy más nemzetközi folyóiratban közölt releváns cikkek adják meg (pl. WALKER et al. 2018).
A javasolt magyar elnevezések alapelve megfogalmazható úgy, mint a következetes következetlenség kivételekkel. A 21. századi tudomány múvelôi számára kézenfekvő a rétegtani nevek angol alakját alapul venni még akkor is, ha azok képzése nem minden esetben következetes. Nem szerencsés, bár nyelvileg megvalósítható lenne a visszatérés az etimologizáló megoldáshoz és az elnevezések eredetének megfelelően helyes (vagy helyesnek vélt) képzéshez. Feltételezzük azonban, hogy az időrétegtani elnevezésekkel leggyakrabban a ma már uralkodóan angol nyelvú nemzetközi szakirodalomban találkozik a magyar szakmai felhasználók többsége is, ezért törekszünk az angol írásmódtól való eltérések mint kivételek számának a minimalizálására. Rámutatva az angol elnevezések esetleges következetlenségére is azt valljuk, hogy ezeknek egy következetes szabályrendszer alapján történő magyarra ültetése eredményezi a leginkább felhasználóbarát névrendszert.

Az elnevezések javasolt képzése a fenti alapelven túl az alábbi megfontolásokon alapul (a felsorolásban a felvetett kérdések a magasabb rendú egységektôl az alacsonyabb rendúek felé következnek):

1. A két legmagasabb rendû kategória egységei, azaz az eonotémák és eonok, valamint az ératémák és érák neveinek végződése -ikum. A legidősebb eon a hadeikum; nevének eredete a görög Hadész, az alvilág istenének mitológiai neve.

2. A proterozoikum rendszerei és időszakai az utolsó kettő kivételével a magyar szaknyelvben szinte alig használatosak, de a nemzetközi szakirodalomban sem elterjedtek. A földrajzi névi eredetú ediacarai képzése az alábbi 5., 8. és 9. pontokat követi. A többi név eredete görög köznévi, melléknévi vagy igei szótôre vezethetô vissza. Az angol -ean végződésû alakok mintájára -i képzős magyar neveket javaslunk (lásd 5. pont), többnyire az angol írásmód megtartásával. Kivételt képez a kriogéni (vagy szintén elfogadható változatban kriogén), ahol mind a krio- előtag, mind a -gén utótag más összetételekben fonetikus magyar írásmóddal meghonosodott.

3. A fanerozoikum rendszereinek és időszakainak nevei olyan mértékben meghonosodtak a szaknyelvben, valamint viszonylag széles körben használatosak az erre épülő tágabb nyelvi környezetben (pl. tankönyvek, társtudományok, ismeretterjesztố és egyéb média), hogy változtatásuk nem indokolt, illetve a nyelvi vagy helyesírási következetesség érdekében esetleg javasolható változtatások meggyökeresedése kétséges lenne.

4. A sorozatok és korok nevei a kainozoikumban a meghonosodott -cén végződést viselik. Az ICS által még hivatalosan be nem vezetett, így a táblázatban nem szereplő, de a szak- és köznyelvben már gyökeret vert legfiatalabb egység az antropocén (ZALASIEWICZ et al. 2017). Az idősebb, két-, illetve háromosztatú egységeken belül egyes esetekben általános formában alsó / középső / felsô, illetve kora / középső / késô elôtag járul a bennfoglaló rendszer és idôszak nevéhez, míg más esetekben -i képzôvel toldalékolt neveket használunk az alacsonyabb rendû egységek képzési szabályaival azonos módon. Különösen a szilur alegységeinek elneve-

$\rightarrow$ 1. ábra. A Nemzetközi időrétegtani táblázat magyar változata $\rightarrow$ Figure 1. Hungarian version of the International Chronostratigraphic Chart 


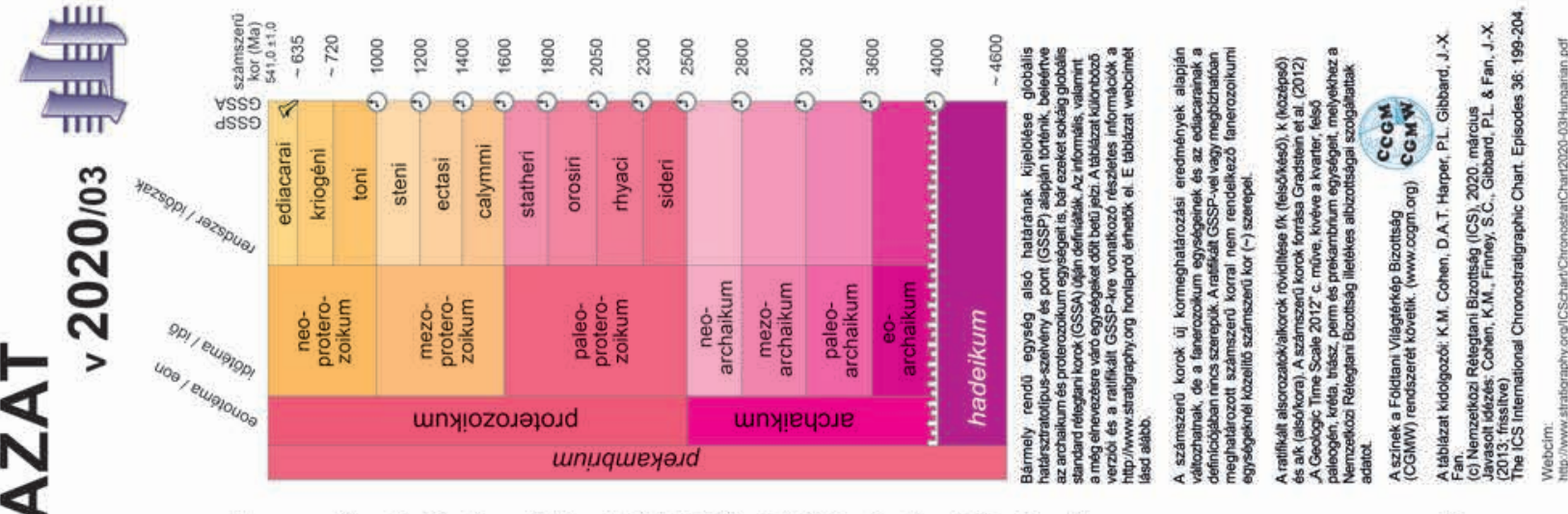

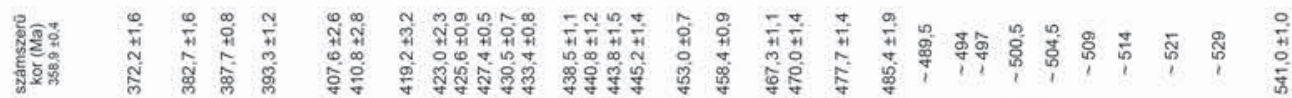

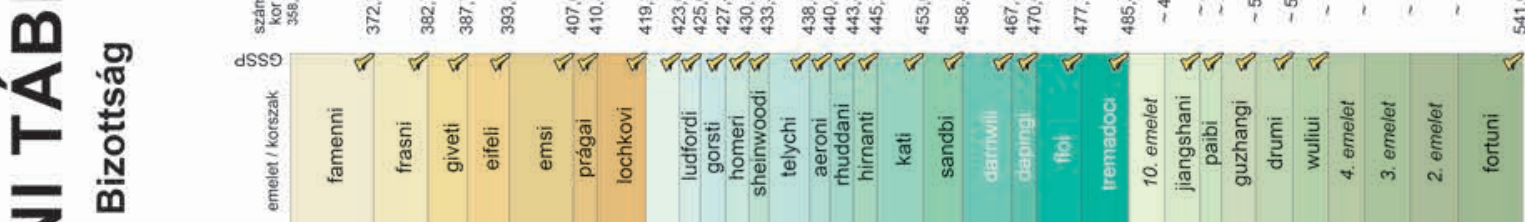

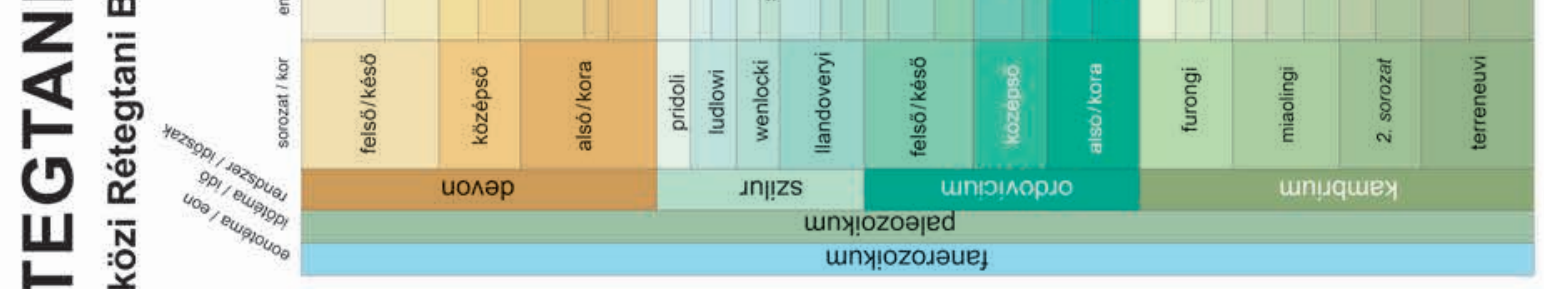

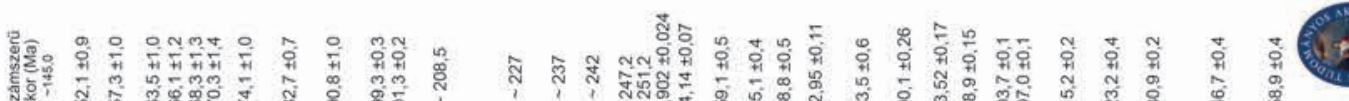

مอ

10

(1)

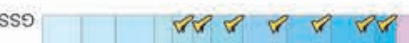

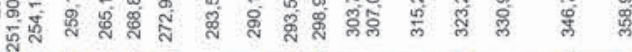

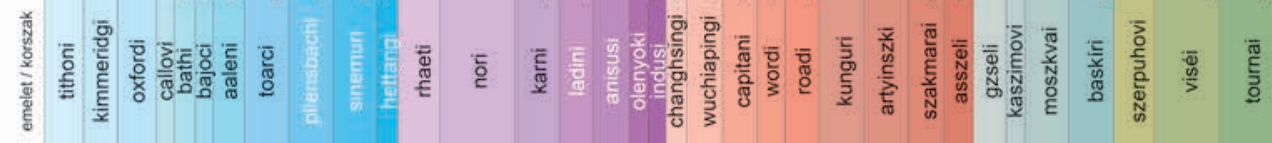

$\overline{\mathrm{N}}$

:O



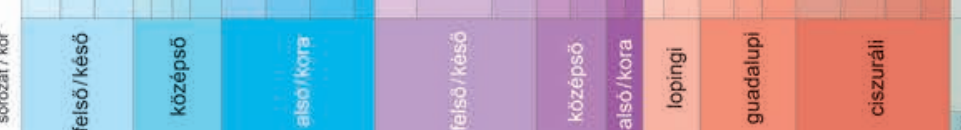

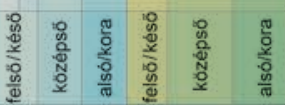

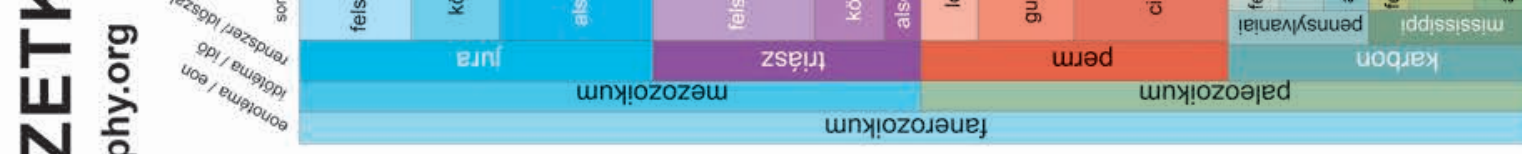

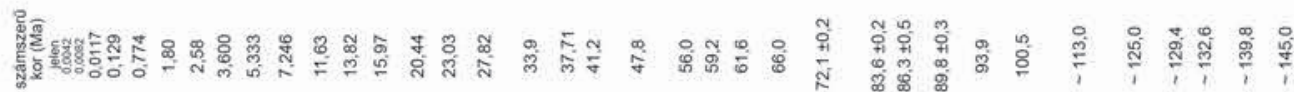

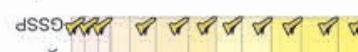

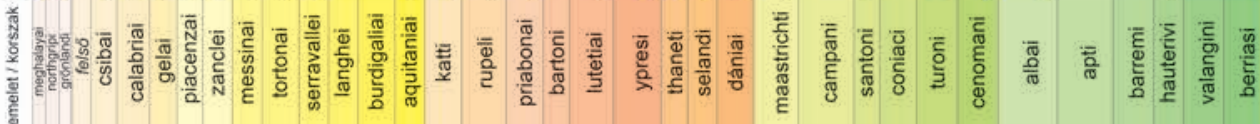

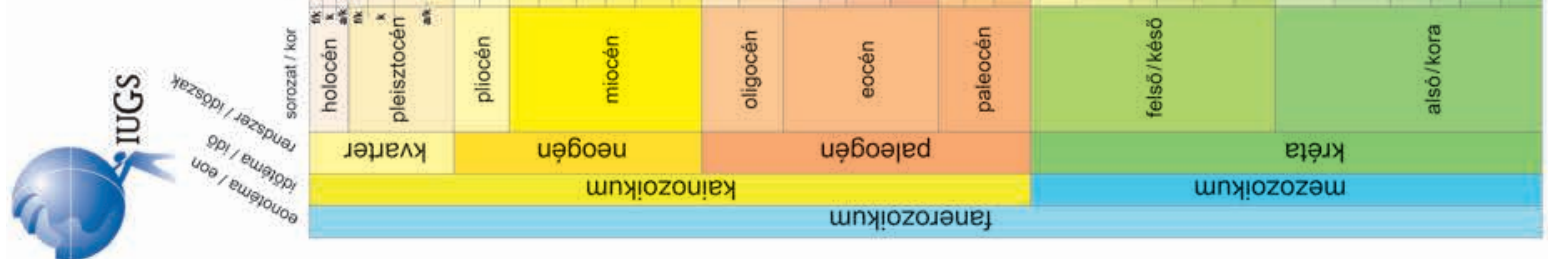


zésénél nem követjük a toldalékolatlan angol szokást, hanem ellátjuk az -i képzővel (ludlowi, wenlocki, llandoveryi).

5. Az-i képző a földtudományi szaknyelvben időrétegtani egységek (leginkább emeletek és korszakok) képzőjeként önálló szerepet is betölt. Ekképpen nem vonatkoznak rá szükségszerűen és szigorúan a földrajzi névből helyhatározói jelző képzésének szabályai, bár azokat irányadónak tekintjük, mivel az időrétegtani egységek neveinek többsége is földrajzi névből képzett.

6. Lényeges eltérés, hogy időrétegtani értelemben az -i képzőt kötôjel nélkül kapcsoljuk. Egybeírva toldalékolunk olyan esetben is, ha az eredeti földrajzi név néma magánhangzóra végződik: ilyenkor a javasolt alakokban a szótô végi néma magánhangzó kiesik (pl. az eddigi gyakorlatnak megfelelően barremi, hauterivi, csakúgy, mint a korábbi írásmódtól eltérôen kimmeridgi).

7. Az y-ra végződő földrajzi nevek esetén az -yi végződést az y elhagyásával -i-re egyszerúsítjük, ha a név eredete nem közismert és az angol névben az y kiesett (pl. kati, sandbi). Ha azonban az angol rétegtani elnevezés y-ra végződik, követjük az általános képzési szabályt (MAGYAR TUDOMÁNYOS AKADÉMIA 2015, ld. 215.) (pl. llandoveryi).

8. További használatra nem javasolt, de a régóta bevett voltuk miatt elfogadottak, azaz hibásnak nem tekinthetők egyes -i képző nélkül használt, földrajzi eredetû elnevezések (pl. bath, cenoman, turon, lásd elektronikus melléklet E1. ábra). Várható az általános szabályt követő, elsődlegesen javasolt alakok (pl. bathi, cenomani, turoni) fokozatos térhódítása.

9. Ékezetet csak olyan esetben használunk, ha az eredeti földrajzi nevet a magyar térképi névanyagban is ékezettel írjuk (pl. ciszuráli). Pusztán fonetikai okokból ékezet alkalmazását vagy egyes hangzók magyar átírását (pl. k, cs) nem javasoljuk (pl. burdigaliai, rupeli, lutetiai, cenomani, callovi, lochkovi).

10. Kerüljük egyes egységek elnevezésében a magyar rétegtani szakirodalomban egykor használatos, magyarosított vagy magyar fonetikus írásmódot, amely félreértésre adhat okot a korábban a modern definícióval nem egyezően alkalmazott nevek esetében (pl. torton, akvitán, burdigál).

11. Amennyiben az eredeti földrajzi névnek létezik magyar vagy magyarosított formájú megfelelője, a rétegtani egység elnevezése annak alapján történik (pl. dániai, grönlandi, moszkvai, prágai).

12. Az angol névben a kiejtés könnyítése érdekében betoldott hangzót elhagyjuk, így a magyar névben a földrajzi név eredeti alakját toldalékoljuk (pl. gelai, tournai, ill. hasonló megfontolásból northgripi).

13. A korábbi gyakorlattól eltérôen a nem földrajzi névből (pl. nép vagy népcsoport nevéből, illetve mitológiai névből) származó elnevezéseket is -i képzôvel toldalékoljuk (pl. tithoni, ladini). A régóta bevett voltuk miatt elfogadott, azaz hibásnak nem tekinthetô az elnevezések -i képző nélkül használt alakja is (pl. tithon, ladin, l. elektronikus melléklet E1. ábra). Várható és támogatandó azonban az általános szabályt követő formák fokozatos térhódítása, mivel a nevek eredete nem széles körben ismert.
14. Különleges nehézséget okoznak a nem latin betûs nyelvek (görög, orosz, japán, kínai) földrajzi neveiből származó elnevezések (1. a 15-18. pontokat), ahol többnyire az angol átírási szokás követését javasoljuk, de megfontolva és néhány esetben előnyösebbnek tartva a magyar átírás alkalmazását.

15. Görög földrajzi nevek latin közvetítéssel mai olaszországi helynevekkel kapcsolatos eredetben fordulnak elő. Bár lehetséges lenne történelmi helynevek magyar átírását alkalmazni (zankléi, gélai), előnyben részesítjük az ehhez közel álló angol írásmódból származtatást (zanclei, gelai).

16. Történelmi okokból a cirill betûs orosz nevek magyar átírási módja közismert, ezért ezekben az esetekben az angol átírási mód követése idegenül hatna a fonetikushoz közeli magyarral szemben. Javasolt tehát az eddig is követett átírási gyakorlat megőrzése (pl. olenyoki, gzseli, kaszimovi, szerpuhovi).

17. Az egyetlen japán eredetú névnél magyar fonetikus átírást javaslunk (csibai).

18. A kínai nevek átírása három különféle módon történhet. Mivel az eredeti kínai helynevek nem széles körben ismertek, a magyar átírás alkalmazása az angol (Wade-Gilesféle), illetve nemzetközi pinjin átírástól való eltérése miatt többnyire zavart okozna. Bár a magyar fordítás alapjául szolgáló táblázat nevei között egyaránt találni angol és nemzetközi átírásúakat is, az eredeti következetlenség megszüntetése felesleges terhet róna a magyar felhasználókra a helyesírásban. Követjük tehát főszabályként a nemzetközi táblázatban bevett írásmódú szótô megtartását (pl. jiangshani, wuchiapingi, changshingi).

19. Az eddigi helyesírási gyakorlatnak megfelelően valamennyi magyar időrétegtani elnevezést kis kezdőbetűvel írjuk (ellentétben az angol nagy kezdőbetûs írásmóddal).

20. Általánosan tagolható két-, illetve háromosztatú geokronológiai egységek esetében kora / középső / késő, illetve kronosztratigráfiai egységeknél alsó / középső / felső elôtag járul a bennfoglaló egység nevéhez. Ezeket mint minőségjelzős szókapcsolatokat a magyar nyelv általános szabályainak megfelelően különírjuk (pl. kora triász, középsó jura, késố kréta). Ez a javaslat változást jelent a CsÁszÁr (2002) által javasolt kötőjeles szakmai írásmódhoz képest, de összhangban van a geokronológiaihoz hasonló értelmú kifejezésekben a történettudományban is bevett gyakorlattal (pl. kora bronzkor, késő reneszánsz).

Bízunk benne, hogy a hazai földtudományi közösség elfogadja a fentieket tükröző javaslatokat (1. ábra), és követésükkel a rétegtani szakmai nyelvhasználat egységesebbé és helyesebbé válik.

\section{Köszönetnyilvánítás}

A fordítás alapjául szolgáló angol eredeti táblázat legfrissebb digitális verziójának rendelkezésre bocsátásáért, a magyar változat támogatásáért és szakmai kérdések tisztázásáért köszönet illeti Kim COHENT és David HARPERT, a 
Nemzetközi Rétegtani Bizottság vezetőségi tagját és elnökét. Hálásak vagyunk BuDAI Tamásnak, PiRos Olgának és SELMECZI Ildikónak a kézirat lektorálásáért és jobbító szándékú kritikai észrevételeikért, PAPP Gábornak és SZTANÓ Or- solyának további szerkesztői megjegyzéseikért, valamint az MTA Rétegtani Albizottságnak javaslataink megvitatásáért. Ez a tanulmány az MTA-MTM-ELTE Paleontológiai Kutatócsoport 322. publikációja.

\section{Irodalom — References}

Cohen, K., Finney, S., GibBARD, P. \& FAn, J. 2013: The ICS International Chronostratigraphic Chart. — Episodes 36, 199-204. https:// doi.org/10.18814/epiiugs/2013/v36i3/002

Cowie, J. W., Ziegler, W., Boucot, A. J., Bassett, M. G. \& Remane, J. 1986: Guidelines and Statutes of the International Commission on Stratigraphy (ICS). - Courier Forschungsinstitut Senckenberg 83, 1-14.

CsÁszÁr, G. 2002: A Magyar Rétegtani Bizottság által jóváhagyott geokronológiai és kronosztratigráfiai terminusok. — Földtani Közlöny 132/3-4, 481-483.

Gradstein, F. M., OgG, J. G. \& Smith, A. G. 2004: A Geologic Time Scale 2004. - Cambridge University Press, Cambridge, 589 p. https://doi.org/10.1017/cbo9780511536045

Gradstein, F. M., OgG, J. G., Schmitz, M. D. \& OGG, G. M. 2012: The Geologic Time Scale 2012. — Elsevier, Amsterdam, 1144 p. https://doi.org/10.1016/c2011-1-08249-8

Magyar TudomÁNyos AKadÉmia 2015: A magyar helyesírás szabályai. 12. kiadás. — Akadémiai Kiadó, Budapest, 611 p.

Remane, J., Bassett, M. G., Cowie, J. W., Gohrbandt, K. H., Lane, H. R., Michelsen, O. \& Naiwen, W. 1996: Revised guidelines for the establishment of global chronostratigraphic standards by the International Commission on Stratigraphy (ICS). — Episodes 19/3, 77-81. https://doi.org/10.18814/epiiugs/1996/v19i3/007

Smith, A. G., Barry, T., Bown, P., Cope, J., Gale, A., Gibbard, P., Gregory, J., Hounslow, M., Kemp, D. \& Knox, R. 2014: GSSPs, global stratigraphy and correlation. — Geological Society, London, Special Publications 404, 37-67. https://doi.org/10.1144/sp404.8

Walker, M., Head, M. H., Berklehammer, M., Bjorck, S., Cheng, H., Cwynar, L., Fisher, D., Gkinis, V., Long, A. \& Lowe, J. 2018 : Formal ratification of the subdivision of the Holocene Series/Epoch (Quaternary System/Period): two new Global Boundary Stratotype Sections and Points (GSSPs) and three new stages/subseries. —Episodes 41/4, 213-223. https://doi.org/10.18814/epiiugs/ 2018/018016

Zalasiewicz, J., Smith, A., Brenchley, P., Evans, J., Knox, R., Riley, N., Gale, A., Gregory, F. J., Rushton, A., Gibbard, P., Hesselbo, S., Marshall, J., OAtes, M., Rawson, P. \& Trewin, N. 2004: Simplifying the stratigraphy of time. — Geology 32/1, 14. https://doi.org/10.1130/g19920.1

Zalasiewicz, J., Waters, C. N., Summerhayes, C. P., Wolfe, A. P., Barnosky, A. D., Cearreta, A., Crutzen, P., Ellis, E., Fairchild, I. J., Gałuszka, A., Haff, P., Hajdas, I., Head, M. J., Ivar Do Sul, J. A., Jeandel, C., Leinfelder, R., McNeill, J. R., Neal, C., Odada, E., Oreskes, N., Steffen, W., Syvitski, J., Vidas, D., Wagreich, M. \& Williams, M. 2017: The Working Group on the Anthropocene: Summary of evidence and interim recommendations. - Anthropocene 19/Supplement C, 55-60. https://doi.org/ 10.1016/j.ancene.2017.09.001

Kézirat beérkezett: 2020. 03. 28. 